\title{
Increased Marketing of Instant Ginger Production by Using Social Media and Improved Packaging Design in Harjomulyo Village, Silo District, Jember Regency
}

\author{
Author \\ Reni Umilasari \\ Correspondence \\ Informatics engineering study program, Universitas Muhammadiyah Jember \\ Email: reni.umilasari@unmuhjember.ac.id
}

\begin{abstract}
:
Ginger (Zingiber officinale) is a rhizome plant that is very popular as a spice and medicinal ingredient. The use of ginger itself varies depending on culture. While in Indonesia, ginger roots and rhizomes are widely used for treatment. Starting from crushed, made into tea, until smeared for healing then the use of ginger root is very thick in the community environment.

Seeing how popular and the various benefits that exist in the ginger plant make masangka in Harjomulyo Village, Silo District, Jember Regency, especially the women of the Al-Hasan Muslimatan Group held an instant ginger powder production activity. This is because Harjomulyo Village is a very strategic plantation area for ginger cultivation so that this plant is quite abundant in the Harjomulyo Village area. The problem that arises that is the marketing of instant ginger production has not been effective. This is due to the absence of special media as a means of promotion / marketing. Until now marketing techniques have only been carried out manually by word of mouth so that not many people know that abundant ginger plants in Harjomulyo Village are produced to become instant ginger ready to drink or as a mixture of drinks or other food ingredients. Therefore there is a need for training and assistance related to production and marketing activities in the hope that it can improve the packaging design to be more attractive so that it has a high selling value; use social media as a new means of marketing instant ginger products for women from the Al-Hasan Muslimatan Group Harjomulyo Village; using Instagram as a marketing tool; as well as using the Android-based "Follower Chief" application to automate marketing using Instagram social media.
\end{abstract}

Keywords: ginger, product marketing, social media, instagram

Received: 06 Desember 2019. Accepted: 5 Januari 2020

\section{Introduction}

Ginger (Zingiber officinale) is a rhizome plant that is very popular as a spice and medicinal ingredient. Rhizome-shaped fingers are bulging in the middle segments. In Europe and India, the spicy sensation caused by making ginger leaves is used as a beverage ingredient and cooking spice. While in Indonesia, ginger roots and rhizomes are widely used for treatment.
Starting from crushed, made into tea, until smeared for healing so that the use of ginger root is very thick in the community environment. Seeing the popularity and variety of benefits that exist in the ginger plant made the community in Harjomulyo Village, Silo Subdistrict, Jember Regency, particularly the women of the Al-Hasan Muslimatan Group held a production of powdered ginger with the aim of meeting the needs of ginger consumption in the family and marketing it to 
various groups with the aim to earn extra income.

The problem that arises that is related to marketing the results of the production of instant ginger has not run effectively. This is due to the absence of special media as a means of promotion / marketing. Until now marketing techniques have only been carried out manually, by word of mouth so that not many people know that the abundant ginger plants in Harjomulyo Village are produced into instant ginger that is ready to drink or as a mixture of drinks / other food ingredients. Thus, to answer these problems marketing methods are needed to be able to introduce instant ginger products from the Harjomulyo village independently and automatically so that people can continue to carry out their daily activities without being interrupted by marketing activities which will certainly take a lot of time and energy.

Based on the description above, we would like to carry out community service, especially the women of the Al-Hasan Muslimatan Group, Harjomulyo Village by raising two main issues as follows:

1. Instant Ginger Production by the Al-Hasan Muslimata Group Harjomulyo Village does not have a packaging design that has a high selling value.

2. The method of instant ginger marketing has not yet utilized social media to its full potential.

\section{Method}

Output expected by all women of AlHasan Muslimatan Group who want to market instant ginger products from Harjomulyo Village is able to apply the rules in marketing using social media so that after going through training the producers can do marketing independently and effectively.The approach that be used in this program is by applying technology directly by analyzing the target market and then adjusting it to marketing strategies.

\section{Result and Discussion}

This section will explain the results of community service activities carried out in the Al Hasan Muslim group in Harjomulyo Village, Silo District, Jember Regency. This activity was carried out on January $8^{\text {th }}, 2019$ and was attended by 31 members of the $\mathrm{Al}$ Hasan Muslim group by prioritizing two core agendas, including:

\section{Design Improvement Program}

The Design Improvement Program consist of:

Discuss the biodata in charge of marketing. This activity was discussed with the core organizers of the Muslimatan Al Hasan group before a training program on the use of social media that invited all Muslim participants.

- Making a logo or product design according to the character of the product and the identity of the gathering of women from the Al-Hasan Muslimatan Group Harjomulyo Village was also held before the training on the use of social media.

- Print designs that have been mutually agreed upon.

- Pasting the design on the packaging is carried out jointly at the recitation program aswell as the Training on the Use of Social Media as a Marketing Facility.

The following below is an example of the design of instant ginger packaging that resulted from several discussions with the core administrators of the Al-Hasan Muslim group.

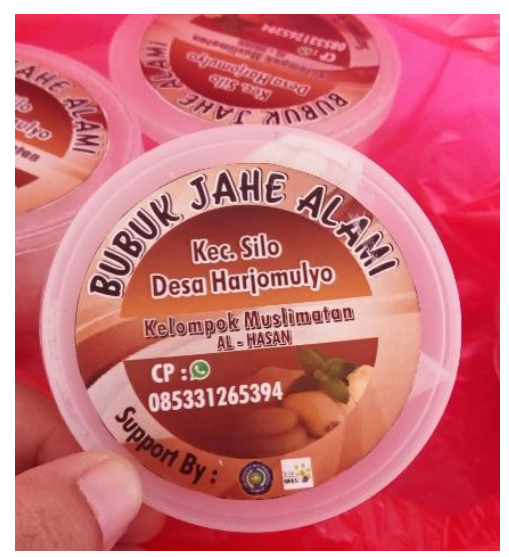

Figure 1. Instant Ginger Packaging Design 


\section{Training on the Use of Social Media as a Marketing Facility}

The second activity needs to be done considering that Instagram is currently a popular media for doing business. On facebook engagement rate per post only reaches around $0.05-1 \%$, while on Instagram it reaches $4.21 \%$. Thus, product photos uploaded will get more interaction (in the form of comments / likes) so that in Indonesia (even the world) many businesses are active on Instagram.

Some things were conveyed during the training which included steps or initial preparations for starting a business on Instagram, including:

- Create an account (must be from iOS / Android)

- Equipping bio with contacts to contact

- Put a website link on the profile

- Take pictures / photos that are beautiful and interesting to look at, one of them by paying attention to the lighting and background photos.

- Using 5 to 10 relevant hashtags that allow Instagram users to see our account if the search matches the hashtags we made.

- Maximum number of product posts 2 times a day or can be more if the product photos that you take are quite interesting.

- For product photos include a complete description, price, and how to buy.

- Don't comment spam on other people's unrelated photos

- It is important to share useful testimonials or writings on our business account.

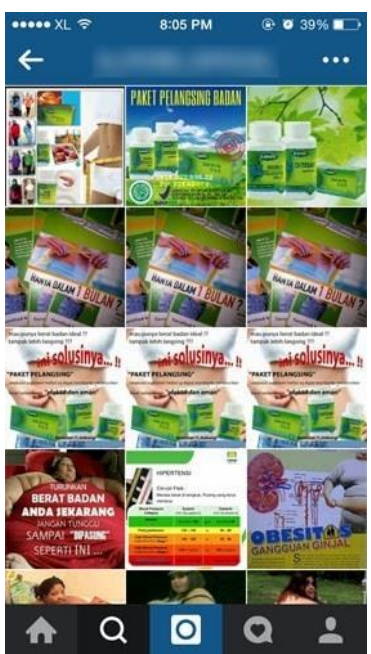

(a)

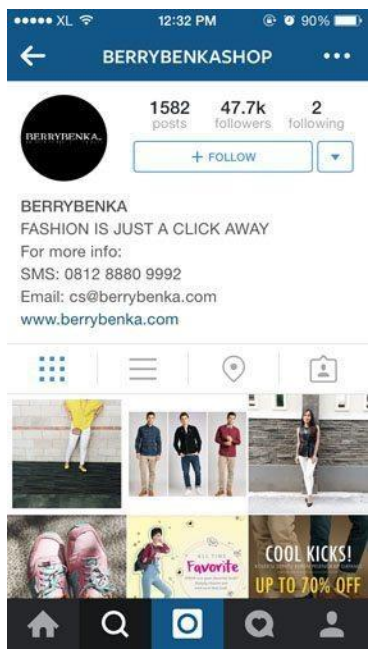

(b)

Figure 2. Display Instagram account for doing business (a) the contents of the posts are not interesting (b.) Interesting posts with a number of followers of tens of thousands.

In Figure 2. (a) Display of uploaded photos is not at all interesting to look at. In addition, many photos are repeated. This can lead to boredom and can result in reduced followers. Next we see a good example, from 50 thousand followers as shown in Figure 1 (b). The account owner puts the slogan, contact, and website link in the profile. Uploaded photos are also interesting to look at because of the good quality. Also important to provide detailed information related to product quality, hashtags, prices, and how to buy. Because the photos are good, even followers who don't want 
to buy won't unfollow. An example of a suitable Instagram account is shown in Figure 3.
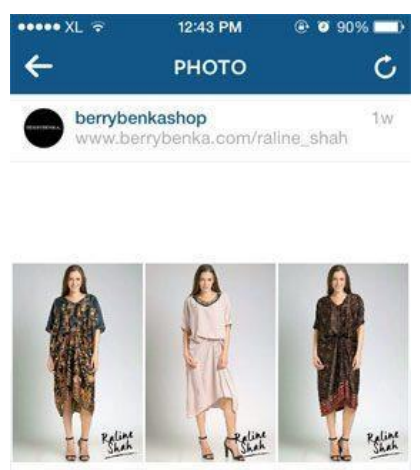

- 144 likes

berrybenkashop Koleksi kaftan Classic Heritage yang cantik dari RalineShahLoveBerrybenka dengan motif batik, aksen payet batu pada bagian garis \#pumpshoes atau \#heels favoritmu unt tampilan \#cantik dan \#feminine! Click http:// berrybenka.com/special/882/raline-shahclassic-heritage to shop! 1. Raisya Kaftan IDR 239.000 2. Rufina Kaftan IDR 259.000 3. Rocio Kaftan IDR 239.000

\#expressyourinnerstar \#ralineshah \#berrybenka \#berrybenkashop merybenkadotcom

berrybenkashop Hai Dear @nutnetnot, mohon maaf untuk item Rufina Kaftan telah sold out. Thankyou :)

\section{i $Q$ O Q :}

Figure 3. Example instagram account that has a lot of followers

\section{References}

Aprilya, T. (2017). Strategi Komunikasi Pemasaran Nadyasfashop Melalui Instagram dalam Meningkatkan Kepercayaan Customer di Samarinda. eJournal Ilmu Komunikasi, 5(1).

Priambada, S. (2015). Manfaat penggunaan media sosial pada usaha kecil menengah(UKM). SESINDO

$2015,2015$.

Purnama, H. (2011). Media Sosial di Era Pemasaran 3.0. Corporate and Marketing Communication. Jakarta.

Rahmawati, D. (2016). Pemilihan dan Pemanfaatan Instagram sebagai media Komunikasi pemasaran Online (studi deskriptif kualitatif pada Akun instagram@freezybrowniezz).Skripsi.
Prodi Ilmu Komunikasi FISIP \& Humaniora UIN Kalijaga Jogjakarta.

Siswanto, T. (2013). Optimalisasi sosial media sebagai media pemasaran usaha kecil menengah. Jurnal Liquidity, 2(1), 8086. 